\title{
STUDI EVALUASI TENTANG KOMPETENSI GURU PENJASORKES SE-KABUPATEN LAMPUNG BARAT
}

\author{
Rahmat Hermawan \\ Universitas Lampung, e-mail:nugafik@yahoo.co.id \\ Imam Safei \\ Universitas Lampung, e-mail: Imamsyafei25@gmail.com \\ Dimas Duta Putra Utama \\ Universitas Lampung, e-mail: Dimasutama33139@gmail.com
}

\begin{abstract}
Abstack
Penelitian ini bertujuan untuk mengetahui gambaran tentang kompetisi guru SD, SMP, SMA/SMK se-Kabupaten Lampung Barat. Tentang kompetisi Pedagogik, Keperibadian, Sosial, dan Profesional. Metode yang digunakan dalam penelitian ini menggunakan Deskriptif Kualitatif. Data dikumpulkan memalui wawancara, pengamatan, dokumentasi, dan angket. Berdasarkan hasil penelitian disimpulkan bahwa (1) Profil guru penjas bertugas di Kabupaten Lampung Barat dari faktor usia relatif tua, masa tugas cukup lama, (2) Aspek Kompetisi pedagogik guru penjas sudah menjalankan dengan sesuai karena sebagian besar sudah mendapatkan PNS dan berstatus sertifikasi, (3) Aspek Kompetisi Kepribadian memiliki prilaku yang dapat di teladani dan dicontoh, (4) secara kompetisi sosial guru penjas mampu berkomunikasi dengan efektif ke beberapa pihak baik di sekolah ataupun pada lingkungan sekitar tempat tinggal, (5) secara kompetisi profesional guru penjas mampu meningkatkan kemampuan individu dengan mengikuti PLPG dan PPG serta penataran yang dilaksanakan di provinsi maupun nasional.
\end{abstract}

Kata Kunci: profil, pedagogik, kepribadian, sosial, profesional

\begin{abstract}
This study aims to find a picture of elementary, junior high, high school / vocational high school teacher competitions in West Lampung Regency. About Pedagogic, Personality, Social and Professional competitions. The method used in this study uses descriptive qualitative. Data is collected through interviews, observations, documentation, and questionnaires. Based on the results of the study it was concluded that (1) The profile of Physical Education teachers on duty in West Lampung Regency from the factors of relatively old age, long term of service, (2) Aspects of Pedagogical Competition Physical Education teachers have run accordingly because most of them have received civil servants and are certified, (3) Aspects of Personality Competition have behaviors that can be modeled and emulated, (4) social competition Physical Education teachers are able to communicate effectively to several parties both at school or in the environment around the place of residence, (5) In a professional competition Physical Education teachers are able to improve their abilities individuals by participating in PLPG and PPG as well as upgrading carried out in the province or nationally.
\end{abstract}

Keywords: Profile, pedagogic, personality, social, professional 


\section{PENDAHULUAN}

Pendidikan jamani olahraga dan kesehatan (PJOK) merupakan mata pelajaran yang berperan penting dalam proses peningkatan keterampilan dan pengembangan emosional serta kebugaran siswadi sekolah dengan beberapa aspek yang ada. Keberhasilan pembelajaran PJOK di sekolah sangat ditentukan oleh peran dan kemampuan sosok seorang guru dalam mengimplementasikan berbagai pengetahuan yang telah diperoleh dibangku kuliah, seperti penerapan modelmodel pembelajaran, penguasaan metode pembelajaran, teknik evaluasi, dan pengetahuan tentang kemampuan mengatasi keterbatasan peralatan olahraga dan mampu untuk menciptakan ruang gerak seluas-luasnya.

Berdasarkan pengamatan dan hasil beberapa penelitian yang dilakukan diberbagai Kabupaten/Kota (Rahmat Hermawan, 2013; 2014; 2015)menunjukan bahwa saat ini sarana dan prasarana untuk kegiatan pembelajaran pendidikan jasmani di sekolah, mulaisekolah dasar sampai sekolah menengah atas (SMA) masih memprihatinkan. Jangankan kuantitasnya, kualitas kelayakan untuk terselenggaranya kegiatan penjasorkes yang nyaman masih jauh dari harapan. Beberapa persoalan yang selalu menjadi alasan dan sulit untuk dihindari, karena antara lain (1)pengadaan sarana dan prasarana pembelajaran penjasorkes tidak semudah yang diharapkan, dan (2)ketergantungan guru penjas pada sarana standard seringkali menghambat aktivitas pembelajaran penjas. Apalagi bila jumlah alat yang dimiliki sekolah tidak sesuai dengan jumlah siswa yang diajar. Sedangkan pembelajaran penjasorkes di sekolah dasar masih terkendala, di antaranya keberadaan struktur fisik dan kondisi fisik serta kemampuan fisik siswa sekolah dasar masih belum memadai untuk kegiatan-kegiatan yang mengacu pada standardisasi alat maupun lapangan. Berat boladan tingginya netbola voli, seringkali mengganggu penguasaan keterampilan dasar bermain voli. Demikian pula dengan permainan bola basket, tingginya ring orang dewasa menjadi kesulitan tersendiri bagi anak usia SD sampai SMA untuk melakukan 'slamdunk' seperti yang sering mereka lihat pada acara siaran TV.Secara psikologis siswa SD,SMP dan SMA masih belum siap dihadapkan pada hal-hal yang bersifat teknis.Hal ini disebabkankarena di tingkatusiaseperti itu lebih cenderung pada kegiatan yang berbentuk permainan yang menyenangkan akan lebih menggugah minat serta motivasi mereka untuk beraktivitas, yang sering dikenal dengan motto "Bermain, Bergerak, Ceria" adalah kata kunci untuk kegiatan.

Melihat fakta dan keadaan guru penjasorkes di lapangan dalam menghadapi berbagai persoalan maupun kemampuan mengatasi kendala, seperti telah digambarkan di atas, maka guru sebagai pekerjaan mulia, yaitu sebagai sosok yang telah memberi kontribusi terhadap banyak orang sehingga menjadikan seseorang berguna baik bagi dirinya sendiri, keluarganya, masyarakat, dan lebih jauh lagi bagi negara dan bangsanya. Tentu tidaklah heran bila melekat sebutan sebagai "pahlawan tanpa tanda jasa". Predikat tersebut mangandung konsekuensi, di satu pihak guru sebagai profesi dituntut dengan berbagai harapan, sebagai teladan, figur yang memiliki skill dan pengetahuan yang cukup mumpuni dari murid atau siswanya sehingga tidak heran guru di berbagai daerah menjadi sosok panutan yang selalu ditiru, apalagi pada zaman sekarang ini adanya perubahan global yang serba kompleks, sehingga guru pun dituntut secara profesionalitas pula (Rahmat Hermawan, 2008). 
Demikian pula di lingkungan dunia pendidikan pun masih sedikit sekali yang memahami pentingnya pendidikan jasmani dan olahraga sebagai bagian yang tidak terpisahkan dalam proses pendidikan anak, sehingga terjadi iklim yang kurang kondusif bagi perkembangan dan keberadaan pelajaran tersebut di sekolah. Tidak sedikit pandangan kepala sekolah maupun guru bidang studi lain yang menganggap bahwa palajaran pendidikan jasmani dan olahraga tidak begitu penting sehingga ketika ada guru yang memiliki jam pelajaran paling sedikit diijinkan atau diperbolehkan untuk mengajar olahraga, demikian pula ketika menghadapi ujian atau ulangan semua siswa dilarang untuk melakukan praktek olahraga dengan alasan mengganggu konsentrasi, bahkan ada kepala sekolah yang melarang siswanya untuk mengikuti kejuaran atau lomba antar sekolah, dan paling ironis sekalli dengan alasan karena bidang pendidikan jasmani dan olahraga dianggap bisa sitangani oleh semua orang sehingga pengurus klub olahraga sekolah (KBO), SD,SMP dan SMA yang mengembangkan induk olahraga (IPOR) bahkan pengawas olahragapun bukan orang yang sesuai dengan bidangnya.

Keadaan seperti itu merupakan gambaran dari lemahnya kompetensi guru penjasorkes, sehingga kompetensi yang meliputi paedagogik, kepribadian, sosial dan profesional kurang diperhatikan Dengan demikian kompetensi merupakan faktor yang utama dalam melaksanakan pembelajaran bagi seorang guru, karena itu kompetensi dianggap sebagai faktor yang dominan untuk menunjukkan performan seorang guru penjasorkes di depan kelas.. Berdasarkan hal tersebut, maka perlu diadakan suatu kajian tentang kompetensi bagi para guru penjasorkes untuk mengetahui sejauhmana mereka dikatakan sebagai pengajar yang profesional, khususnya pada guru penjasorkes di Kabupaten Lampung Barat.

\section{METODE}

Metode yang digunakan dalam penelitian ini penulis menggunakan pendekatan deskriptif kualitatif. Penulis melakukan penelitian dengan studi deskriptif analitis karena sesuai dengan sifat masalah serta tujuan penelitian yang ingin diperoleh dan bukan menguji hipotesis, tetapi berusaha untuk memperoleh gambaran yang nyata tentang bagaimana kompetensi guru pendidikan jasmani diesuaikan pada masing-masing jenjang pendidikan. Sifat kualitatif yang ada dalam penelitian ini mengharuskan peneliti menjadi sosok kunci dalam pembuatan instrumen penelitian.Dipilihnya pendekatan kualitatif dalam penelitian ini didasarkan pada alasan bahwa permasalahan yang dikaji dalam penelitian ini yaitu gambaran tentang kompetensi guru pendidikan jasmani di SD/MI, SMP/MTs, dan SMA/SMK/MA yang sudah sertifikasi mupun yang belum se Kabupaten Lampung Barat. Untuk memperoleh data yang diperlukan dalam penelitian ini, penulis menggunakan teknik pengumpulan data sebagai berikut:

1. Observasi, Observasi yaitu pengamatan yang meliputi kegiatan pemusatan perhatian terhadap suatu objek dengan menggunakan seluruh alat indera. Arikunto (2009:129) berpendapat bahwa: "Observasi dilakukan oleh pengamat dengan menggunakan instrumen pengamatan maupun tanpa instrumen pengamatan." Pengamatan memungkinkan pengamat untuk melihat dunia sebagaimana yang dilihat oleh subjek penelitian, hidup pada saat itu, menangkap arti fenomena dari segi pengertian subjek, menaangkap kehidupan budaya dari segi pandangan yanng dianut oleh para subjek pada 
keadaan waktu itu. Pengamatan memungkinkan peneliti merasakan apa yang dirasakan dan dihayati oleh subjek sehingga memungkinkan pula peneliti menjadi sumber data.

2. Wawancara, Wawancara menurut Esterberg (Sugiyono 2009:317) adalah: "Pertemuan dua orang untuk bertukar informasi dan ide melalui tanya jawab, sehingga dapat dikonstruksikan makna dalam suatu topik tertentu. Menurut Nasution (2003:73), tujuan wawancara untuk "mengetahui apa yang terkandung dalam pikiran dan hati orang lain, bagaimana pandangannya tentang dunia, yaitu hal-hal yang dapat kita ketahui melalui observasi."

3. Studi Dokumentasi, Studi Dokumentasi merupakan pelengkap dari penggunaan metode observasi dan wawancara dalam penelitian kualitatif. Arikunto (2009:236) mengatakan bahwa "metode dokumentasi merupakan salah satu cara mencari data mengenai hal-hal atau variabel berupa catatan transkrip, buku, surat kabar, majalah, prasasti, notulen rapat, legger, agenda dan sebagainya". Data yang diperoleh dari studi dokumen dapat menjadi narasumber bagi peneliti selain wawancara dan observasiAngket, untuk mengumpulkan sejumLh informasi yang menyangkut sebagai dat tentang diri responden termasuk segala bentuk kegiatan.

Berdasarkan data kualitatif maupun kuantitatif, melalui pengamatan, wawancara, dokumentasi dan angket, maka diperoleh sejumlah data antara lain; lokasi sekolah dan profil guru penjasorkes SD, SMP dan SMA/SMK, di Kabupaten Lampung Batar. Kompetensi profesional dan pedagogik, kompetensi kepribadian dan kegiatan sosial. Secara geografi Kabupaten Lampung barat merupakan salah satu kabupaten di Lampung, terdapat 15 kecamatan, yaitu Air Hitam, Balik Bukit,
Bandar Negeri Suoh, Batu Ketulis, Batubrak, Belalau, Gedung Suriah, Kebun Tebu, Lumbok Seminung, Pagar Dewa, Sekincau, Sukau, Sumber Jaya, Suoh, Berdasarkan informasi dan pengamatan di lapangan letak sekolah satu dengan yang lainnya cukup bervariasi jaraknya terutama untuk tingkat sekolah dasar. Sedangkan sekolah tingkat menengah pertama (SMP), dan untuk sekolah SMA setiap kecamatan memiliki minimal 3 SMA sederajat.

Tabel 1. Jenis Kelamin Responden

\begin{tabular}{c|c|c|c|c}
\hline \multirow{2}{*}{$\begin{array}{c}\text { Jenis } \\
\text { Kelamin }\end{array}$} & \multicolumn{2}{|c|}{ Pria } & \multicolumn{2}{c}{ Wanita } \\
\cline { 2 - 5 } & $\mathbf{F}$ & $\%$ & $\mathbf{F}$ & $\%$ \\
\hline SD & 38 & 50 & 29 & 33,33 \\
\hline SMP & 58 & 88.71 & 4 & 11,29 \\
\hline SMA/SMK & 1 & 79.16 & 0 & 29,83 \\
\hline Jumlah & 97 & & 33 & \\
\hline
\end{tabular}

Pada Tabel1 di atas menunjukkan bahwa guru penjasorkes di Kabupaten Lampung Barat jumlah antara pria dan wanita sangat jauh sekali, yaitu 97 Pria dan 33 wanita yang terdiri dari 38 orang guru SD, 29 orang guru SMP, sedangkan sisanya guru SMA dan SMK sebanyak1 orang.

Tabel 2. Umur Responden

\begin{tabular}{c|c|c|c|c|c|c}
\hline \multirow{2}{*}{ Umur } & \multicolumn{2}{c|}{ SD } & \multicolumn{2}{c|}{ SMP } & \multicolumn{2}{c}{$\begin{array}{c}\text { SMA/S } \\
\text { MK }\end{array}$} \\
\cline { 2 - 7 } & $\begin{array}{c}\text { Pri } \\
\text { a }\end{array}$ & $\begin{array}{c}\text { Wa } \\
\text { nita }\end{array}$ & Pria & $\begin{array}{c}\text { Wa } \\
\text { nita }\end{array}$ & $\begin{array}{c}\text { Pri } \\
\text { a }\end{array}$ & $\begin{array}{c}\text { Wa } \\
\text { nita }\end{array}$ \\
\hline$\leq 20$ tahun & - & - & - & - & - & - \\
\hline $21-25$ tahun & 2 & 1 & 5 & - & & \\
\hline $26-30$ tahun & 5 & 3 & 10 & - & - & - \\
\hline $31-35$ tahun & 1 & 7 & 16 & 3 & 1 & - \\
\hline $36-40$ tahun & 4 & 6 & 12 & - & - & - \\
\hline $41-45$ tahun & 1 & 10 & 15 & 1 & - & - \\
\hline $46-50$ tahun & 1 & 1 & 13 & - & - & - \\
\hline$>50$ tahun & 3 & 2 & 3 & - & - & - \\
\hline Jumlah & 3 & 29 & 58 & 4 & 1 & - \\
\hline
\end{tabular}


Berdasarkan Tabel.2 di atas menunjukkan bahwa guru penjasorkes yang paling banyak berada pada rentang umur 31-35 dan 41-45 tahun yaitu 37 dan 36 orang, terutama guru yang berjumlah 10 orang, dan yang berada di atas 50 tahun sebanyak 8 orang terutama pada guru. Sedangkan sisanya menyebar pada tingkatan lainnya.

Tabel 3. Status Pegawai Responden

\begin{tabular}{c|c|c}
\hline \multirow{2}{*}{ Status Pegawai } & \multirow{2}{*}{ PNS } & Honor \\
\cline { 1 - 1 } SD & 42 & 25 \\
\hline SMP & 29 & 29 \\
\hline SMA/SMK & 1 & 0 \\
\hline Jumlah & 72 & 54 \\
\hline
\end{tabular}

Berdasarkan tabel 3. di atas bahwa guru penjasorkes mayoritas sudah berstatus sebagai pegawai negeri (PNS) sebanyak 72 orang (yang paling banyak pada guru SD, yakni 42 orang) sedangkan sisanya sebanyak 54 orang masih status guru honorer.

Tabel 4. Sertifikasi Dijalani Responden

\begin{tabular}{l|l|l|l|l}
\hline \multirow{2}{*}{$\begin{array}{c}\text { Sertifikasi } \\
\text { yang } \\
\text { Dijalani }\end{array}$} & \multicolumn{2}{|c|}{ Sudah } & \multicolumn{2}{c}{ Belum } \\
\cline { 2 - 5 } & Pria & Wanita & Pria & Wanita \\
\hline SD & 28 & 16 & 10 & 13 \\
\hline SMP & 34 & 3 & 20 & 1 \\
\hline SMA & 1 & 0 & 0 & 0 \\
\hline Jumlah & 63 & 19 & 30 & 14 \\
\hline
\end{tabular}

Berdasarkan tabel di atas menunjukkan bahwa guru penjasorkes yang sudah memperoleh sertifikasi ialah 82 orang, sedangkan yang belum sebanyak 44 orang. Dari hasil wawancara diperoleh kondisi keadaan tetang tunjangan yang profesi akibat keberhasilan mendapat sertifikat pendidik, baik melalui jalur portofolio maupun PLPG. Dari jumlah orang guru yang memperoleh sertifikasi, beberapa diantaranya $R$ menuturkan sebagai berikut; " saya merasa bahagia dapat sertifikasi shingga dapat tunjangan, untuk mnambah biaya keprluan rumah tangga atau konomi keluarga", Begitu pula pendapat $\mathrm{BH}$ dan $\mathrm{S}$, yang kebetulan keduanya sudah disertifikasi karena batas usia, "alhamdulillah dengan adanya sertifikasi bisa membantu kesulitan kuangan kami, trutama mmbantu biaya anak kami yang sdang mnuntut ilmu di bangku kuliah"

Dari beberapa pendapat di atas dapat disimpulkan bahwa dengan adanya sertifikasi bagi guru telah meningkatkan pendapatan mereka. Artinya, dari aspek kesejahteraan pun akan meningkat pula. Namun, masih banyak pekerjaan rumah yang harus dihadapi oleh para guru, khususnya guru penjasorkes terutama dalam meningkatkan profesionalitasnya, termasuk meningkatkan kinerja, seperti jawaban dari beberapa guru penjasorkes atas pertanyaan yang telah dilontarkan, baik pada guru SD, SMP maupun SMA mengenai pelaksanaan pembelajaran yang dirasakan masih membutuhkan perhatian sekaligus solusi penanganannya atau pemecahan.

Adapun permasalahan yang perlu perhatian bagi guru sekolah dasar, antara lain (1) pemahaman dan isi kurikulum 2013, (2) pemahaman konsep penjasorkes, dan cara mengatasi keterbatasan peralatan. Sedangkan para guru SMP dan SMA menyampaikan pernyataannya berkisar tentang; (1) pemahaman kurikulum 2013, (2) teknik dan pelaksanaan penilaian, (3) pemahaman konsep penjasorkes, (4) perangkat RPP, dan (5) cara mengatasi keterbatasan peralatan (sarana \& prasarana). Jadi semua guru membutuhkan sosialisasi tentang kurikulum 2013, pemahaman konsep penjasorkes, pembuatan perangkat pembelajaran, teknik dan pelaksanaan penilaian, serta 
cara mengatasi keterbatasan perlatan sarana \& prasarana pembelajaran. Aspek Kepribadian, Pada aspek kompetensi kepribadian diperoleh sejumlah data berdasarkan wawancara dan pengamatan menunjukan bahwa sebagian besar guru penjasorkes kurang memperhatikan etika dan kepatutan sebagai guru olahraga dan kesehatan. Kegiatan Sosial, Dengan banyaknya membantu pihak lain, maka bisa dikatakan bahwa guru penjasorkes pada umumnya sudah memiliki kompetensi sosial. Berbagai kegiatan organisasi banyak diikuti oleh para guru penjasorkes khususnya yang berada Di Lampung Barat, Kabupaten Lampung Barat bahkan tingkat propinsi. Kegiatan yang dilakukan di tingkat sekolah seperti KBO, O2SN. Begitu pula untuk kegiatan perlombaan dan pertandingan yang bersifat insidental, mulai tingkat Kecamatan, Kabupaten hingga Propinsi sering mereka ikuti, baik sebagai panitia maupun mendampingi siswanya sebagai peserta.

Pedagogik, dengan jumlah guru yang sudah memiliki sertifikasi 72 orang, dengan ini dikatakan bahwa guru memilik kemampuan dalam mengajar yang dapat di teladani dan di contoh bagi peserta didk maupun dari pihak luar. Kemampuan seorang guru yang mengajar menjadikan proses pembelajaran lebih berkembang dengan proses perkemabngan yang berada di luar kelas.

Profesional, kemampuan menjadi guru profesional adalah kewajiban yang harus dimiliki. Beberapa poin dikatakan bahwa guru harus memiliki tingkat profesional yang baik. Dengan selalu mengikuti perkembangan pembelajaran yang ada. Pembuktian hal itu dengan guru PJOK mengikuti pelatihan/penataran yang dilaksanakan tingkatan daerah sampai nasional. Program percepatan sertifikasi yang dulu PLPG kemudian sekarang menjadi PPG guru PJOK mengikuti dengan harapan setelah selesai menjalankan kegiatan tersebut keluar menjadi guru yang mampu dikatakan menjadi profesional.

\section{PEMBAHASAN}

Berdasarkan temuan penelitian tentang jenis kelamin responden atau guru pendidikan jasmani, olahraga dan kesehatan (penjasorkes) yang berada di wilayah Kabupaten Lampung Barat, Lampung yakni berjumlah 184 orang, terdiri dari 157 orang pria dan 29 orang wanita. Keadaan demikian menunjukan bahwa mayoritas seorang guru penjasorkes adalah seorang pria. Artinya, kesempatan untuk menjadi guru sama tetapi masih banyak diminati oleh kaum pria. Tentang umur atau usia rata-rata para guru penjasorkes yang bertugas di kota tersebut nampaknya yang paling banyak berada dikisaran 40 tahun ke atas, hal ini menunjukan bahwa usia mereka termasuk relatif usia tua, dan apabila ditinjau dari segi produktivitas sudah mulai munurun, karena batas usia pensiun guru sesuai peraturan pemerintah hanya mencapai usia 50 tahun. Jadi, mereka hanya tinggal sekitar 10 tahun lagi untuk mengabdi atau melaksanakan tugasnya. Keadaan ini sudah barang tentu mereka sudah tidak dapat digolongkan pada usia muda lagi atau dengan kata lain mereka sudah menikah atau pernah mengalami pernikahan.

Dari uraian diatas dapat disimpulkan bahwa secara kompetensi pedagogik para guru penjasorkes di Kabupaten Lampung Barat sudah sesuai, hal ini ditunjukan dengan, selain pendidikan yang sudah dijalani sesuai dengan ketentuan perundang-undangan, juga telah memiliki kemampuan (1) pemahaman terhadap peserta didik, (2) mampu membuat perancangan pembelajaran, (3) mampu melaksanakan pembelajaran yang kondusif, 
dan (4) mampu merancang dan melaksanakan evaluasi hasil belajar secara berkesinambungan.

Kompetisi kepribadian dari pendapat beberapa sumber tentang kepribadian guru penjasorkes yang dikemukakan di atas maka dapat disimpulkan bahwa kepribadian guru pada umumnya cukup positif, yaitu mudah bergaul dan bekerja sama. Hal ini sesuai dengan uraian tentang kompetensi Kepribadian yang dikemukakan dalam Modul Materi Pelajaran Penjaskes A FKIP Unila (2011:22), yaitu (1) kepribadian yang mantap dan stabil, bertindak seuai dengan norma hukum, social, banga sebagai guru dan memiliki kosistensi dalam bertindak, (2) kepribadian yang dewasa, , (3) kepribadian yang arif, (4) kepribadian yang berwibawa, dan (5) akhlak mulia dan dapat menjadi teladan.

Berdasarkan temuan penelitian tentang kompetensi sosial, bahwa guru penjasorkes pada umumnya sudah memiliki kompetensi sosial. Hal ini ditunjukan dengan berbagai kegiatan organisasi yang diikuti khususnya, mulai tingkat Kecamatan, Kota, bahkan Propinsi. Untuk kegiatan yang dilakukan di tingkat sekolah seperti KBO, O2SN. Begitu pula untuk kegiatan perlombaan dan pertandingan yang bersifat insidental, mulai tingkat Kecamatan, Kota hingga Propinsi sering mereka ikuti, baik sebagai panitia maupun mendampingi siswanya sebagai peserta.

Modul

Materi Pelajaran Penjaskes A FKIP Unila (2011:24), yaitu (1) mampu berkomunikasi dan bergaul secara efektif dengan peserta didik, (2) mampu berkomunikasi dan bergaul secara efektif dengan sesame pendidik dan tenaga kependidikan, dan (3) mampu berkomunikasi dan bergaul secara efektif dengan orang tua/wali peserta didik dan masyarakat sekitar. Kompetisi profesional berdasarkan temuan penelitian tentang guru penjasorkes di Kabupaten Lampung Barat yang sudah memperoleh sertifikasi ialah 82 orang, sedangkan yang belum sebanyak 44 orang. Hal ini menunjukan masih belum meratanya kesempatan memperoleh sertifikasi bagi guru di wilayah tersebut. Modul Materi Pelajaran Penjaskes A FKIP Unila (2011:21). Oleh karena itu, dengan pendidikan yang relatif tinnggi diharapkan mampu menguasai materi kurikulum serta struktur dan metodologi keilmuannya. yaitu (1) menguasai substansi keilmuan yang terkait dengan bidang studi dan mampu menerapkan konsep keilmuan dalam kehidupan sehari-hari, dan (2) menguasai lengkah-langkah penelitian dan kajian kritis untuk memperdalam pengetahuan atau materi bidang studi.

\section{SIMPULAN}

Berdasarkan uraian tentang hasil dan pembahasan maka selanjutnya dapat disimpulkan sebagai berikut:

1. Profil guru penjasorkes yang bertugas di Kabupaten Lampung Barat menunjukan bahwa dari faktor usia termasuk relative sudah berumur, terutama SD, SMP, dan SMA sehingga bila ditinjau dari segi produktivitas sudah mulai menurun. Demikian pula masa tugas mereka relatif cukup lama (rata-rata di atas 20 tahun), sudah barang tentu pengalaman mengajar pun cukup lama pula dan mayoritas sudah menjadi PNS.

2. Secara Kompetisi Profesional relatif masih banyak guru penjasorkes di Kabupaten Lampung Barat yang belum memperoleh sertifikasi sebagai pengakuan profesi pendidik dan sebagai memenuhi amanat undangundang. 
3. Secara kompetensi pedagogik para guru penjasorkes di Kabupaten Lampung Barat sudah sesuai, hal ini ditunjukan dengan, selain pendidikan yang telah dijalani sesuai dengan ketentuan perundang-undangan, juga telah memiliki kemampuan (1) pemahaman terhadap peserta didik, (2) mampu membuat perancangan pembelajaran, (3) mampu melaksanakan pembelajaran yang kondusif, dan (4) mampu merancang dan melaksanakan evaluasi hasil belajar secara berkesinambungan.

4. Secara kompetensi sosial para guru penjasorkes di Kabupatn Lampung Barat telah mampu berkomunikasi dan bergaul secara efektif dengan berbagai pihak, seperti dengan peserta didik, sesama pendidik dan tenaga kependidikan, dan orang tua/wali peserta didik serta masyarakat sekitar.

5. Secara kompetensi kepribadian para guru penjasorkes di Kabupaten Lampung Barat memiliki perilaku yang bisa diteladani oleh peserta didik.

\section{DAFTAR PUSTAKA}

Arikunto, Suharsimi dan Cepi Safrudin Abdul Jabar. (2009). Evaluasi Program Pendidikan. Jakarta. Bumi Aksara.

Estrada, E., Pujianto, D., \& Arwin, A. (2019). Persepsi Kepala Sekolah Terhadap Kinerja Guru Pjok Sekolah Menengah Atas Negeri Di Kota Bngkulu. Kinestetik, 3(2), 198-207.

Ginting, Abdurrakhman. (2008). Esensi Praktis Belajar dan Pembelajaran. Yogyakarta. Humaniora.

Hamalik, Oemar. (2009). Pendidikan Guru (Berdasarkan Pendekatan Kompetensi). Jakarta. Bumi Aksara.

Husdarta. H.J.S. (2009). Manajemen Pendidikan Jasmani. Bandung. Alfabeta.
Hermawan, Rahmat. (2008).Sertifikasi Merupakan Pengakuan Profesi Guru. Makalah. Disampaikan dalam Seminar Sehari di depan Guru Penjaskes Se- Kecamatan Pangalengan Kabupaten Bandung, tanggal 20 Maret 2008.

Hermawan, Rahmat (2014). Studi Evaluasi Tentang Kompetensi Guru Penjasorkes Se- Kecamatan Tanjung karang Barat Kota Bandar Lampung. Jurnal Pendidikan Progresif 4(1), 7992.

Hermawan, Rahmat (2014). Studi Evaluasi Tentang Kompetensi Guru Penjasorkes Kabupaten Pringsewu. LaporanPenelitian. LPPM Universitas Lampung. Bandar Lampung.

Hermawan, Rahmat dan Sudirman Husin (2015). Studi Evaluasi tentang Kompetensi Guru Penjasorkes Kota Metro LaporanPenelitian. LPPM Universitas Lampung. Bandar Lampung.

Lutan, Rusli. (2000). Manajemen Pendidikan jasmani. Bandung. Depdiknas.

Mahendra, Agus. (2008). Asas dan Falsafah Pendidikan Jasmani. Bandung. FPOKUPI Bandung.

Moleong, J. Lexy. (2000). Metode Penelitian Kualitatif. Bandung. PT Remaja Rosda Karya.

Mulyasa. E. (2007). Kurikulum Tingkat Satuan Pendidikan. Bandung. PT Remaja Rosda Karya.

Mulyasa. E. (2008). Menjadi Guru Profesional: Menciptakan Pembelajaran Kreatif dan Menyenangkan. Bandung. PT Remaja Rosda Karya.

Nasution. (2003). Metode Research. Bandung. PT Jemar.

Sagala, Syaiful. (2007). Konsep dan Makna Pembelajaran. Bandung. Alfabeta. 
Sarosa, Samiaji. (2012). Penelitian Kualitatif (Dasar-Dasar). Jakarta. Indeks.

Sugiyono. (2009). Metode Penelitian Pendidikan (Pendekatan Kuantitatif \& Kualitatif). Bandung. Alfabeta.

Suherman, Adang dan Agus Mahendra. (2001). Menuju Perkembangan Menyeluruh. Menyiasati Kurikulum Pendidikan Jasmani di Sekolah Menengah Umum. Jakarta. Depdiknas.

Susilo, Joko Muhammad. (2007). Kurikulum Tingkat Satuan Pendidikan. Manajemen Pelaksanaan dan Kesiapan Sekolah Menyongsongnya. Yogyakarta. Pustaka Pelajar.

Usman, Moh. Uzer. (2007). Menjadi Guru Profesional. Bandung. PT Remaja Rosda Karya.

Yusuf. (2001). Pertumbuhan, Perkembangan Peserta Didik. Bandung. FPOK-UPI Bandung.

Universitas Lampung, 2009. Format Penullisan Karya Ilmiah Universitas Lampung. Bandar Lampung. 